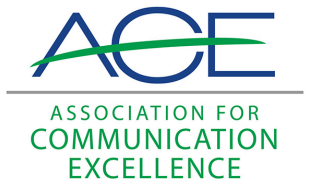

Journal of Applied Communications

\title{
A Case Study of Using Metacognitive Reflections to Enhance Writing Skills and Strategies in an Agricultural Media Writing Course
}

Tobin Redwine

Holli R. Leggette

Brooke Prather

Follow this and additional works at: https://newprairiepress.org/jac c) (i) (2)

This work is licensed under a Creative Commons Attribution-Noncommercial-Share Alike 4.0 License.

\section{Recommended Citation}

Redwine, Tobin; Leggette, Holli R.; and Prather, Brooke (2017) "A Case Study of Using Metacognitive Reflections to Enhance Writing Skills and Strategies in an Agricultural Media Writing Course," Journal of Applied Communications: Vol. 101: Iss. 1. https://doi.org/10.4148/1051-0834.1014

This Research is brought to you for free and open access by New Prairie Press. It has been accepted for inclusion in Journal of Applied Communications by an authorized administrator of New Prairie Press. For more information, please contact cads@k-state.edu. 


\title{
A Case Study of Using Metacognitive Reflections to Enhance Writing Skills and Strategies in an Agricultural Media Writing Course
}

\author{
Abstract \\ Writing is a foundational skill in agricultural communications, and metacognition the learning and \\ understanding of such skill. Integrating reflection into a writing course is one way to enhance students' \\ metacognition and metacognitive awareness as reflection provides writers an opportunity to become a \\ critic of their writing experiences. However, what happens when students reflect on their metacognitive \\ awareness during and throughout the writing process? Using a qualitative and quantitative content \\ analysis, we interpreted 16 students' metacognitive writing reflections at four points in an advanced \\ media writing course. We identified and analyzed emergent themes from the reflections and measured \\ the frequency of each theme over the duration of the course. Three major themes emerged: a) \\ metacognitive awareness of writing skills, b) metacognitive awareness of writing strategies, and $c$ ) \\ metacognitive awareness of knowledge transfer. A total of 13 sub-themes were identified further \\ characterizing the themes. Interviewing (a writing skill) emerged more in the third reflection than any \\ other time, and revision (a writing strategy) emerged more at the beginning and end of the course than in \\ the middle. Additionally, participants reflected less about outcomes (a component of knowledge transfer) \\ at the end of the course and more about their plans for the future. Findings support the value of \\ metacognitive reflections as a transformational instruction tool. Practitioners and writing instructors in \\ agricultural communications should be cognizant of skills, strategies, and knowledge transfer as they \\ plan and implement writing education and be adaptive and flexible to meet students' changing \\ metacognitive awareness.
}

\section{Keywords}

Media Writing, Metacognition, Reflection, Writing Skills and Strategies 


\title{
A Case Study of Using Metacognitive Reflections to Enhance Writing Skills and Strategies in an Agricultural Media Writing Course
}

\author{
Tobin Redwine, Holli R. Leggette, and Brooke Prather
}

\begin{abstract}
Writing is a foundational skill in agricultural communications, and metacognition the learning and understanding of such skill. Integrating reflection into a writing course is one way to enhance students' metacognition and metacognitive awareness as reflection provides writers an opportunity to become a critic of their writing experiences. However, what happens when students reflect on their metacognitive awareness during and throughout the writing process? Using a qualitative and quantitative content analysis, we interpreted 16 students' metacognitive writing reflections at four points in an advanced media writing course. We identified and analyzed emergent themes from the reflections and measured the frequency of each theme over the duration of the course. Three major themes emerged: a) metacognitive awareness of writing skills, b) metacognitive awareness of writing strategies, and c) metacognitive awareness of knowledge transfer. A total of 13 sub-themes were identified further characterizing the themes. Interviewing (a writing skill) emerged more in the third reflection than any other time, and revision (a writing strategy) emerged more at the beginning and end of the course than in the middle. Additionally, participants reflected less about outcomes (a component of knowledge transfer) at the end of the course and more about their plans for the future. Findings support the value of metacognitive reflections as a transformational instruction tool. Practitioners and writing instructors in agricultural communications should be cognizant of skills, strategies, and knowledge transfer as they plan and implement writing education and be adaptive and flexible to meet students' changing metacognitive awareness.
\end{abstract}

\section{KEY WORDS}

Media Writing, Metacognition, Reflection, Writing Skills and Strategies

\section{INTRODUCTION}

Writing is a "complex integrated activity" (Leggette, Rutherford, \& Dunsford, 2015, p. 250) that serves as a foundational skill for college graduates in agricultural communications and "requires more knowledge and skills than it does talent, especially when it comes to creating informative texts" (Kuzu, 2016, p. 39). Yet, many new graduates lack fundamental writing skills, thereby, finding themselves misunderstood, inadequate, unmotivated to write, and hating the writing process (Kavcar, Oguzkan, \& Sever, 2012).

Some variations exist, however, in what researchers have classified as important media writing skills and strategies. Lingwall and Kuehn (2013) divided writing into five categories_elaborative/surface, reflective/revisionist, writing self-efficacy, 
writing apprehension, and social media/professional. Three of the five directly apply to the current study: elaborative/ surface (thoughts about writing and its importance), reflective/revisionist (willingness and desire to review, edit, and revise), and writing self-efficacy (perceived confidence in writing skills, such as spelling, punctuation, grammar, organization, paragraph development, and audience). In Poniatowski's (2012) study of preparing students for writing-intensive programs, she included basic grammar and punctuation, spelling and word usage, applying Associated Press style, and evaluating stories for clarity, appropriate style, and grammatical correctness as important course outcomes. Additionally, Carpenter, Grant, and Hoag (2016) identified "'telling stories,' 'asking questions,' 'informing people,' and being 'a voice for the underprivileged and underrepresented groups'" as essential reporting skills for effective journalists (p. 18).

At the center of learning and understanding any type of skill is metacognition or the "refer[ence] to one's knowledge concerning one's own cognitive processes or anything related to them" (Flavell, 1976, p. 232). Instrumental to metacognition is self-regulation and reflection (National Research Council, 2000), but students often lack opportunities to apply such practices (Nist \& Simson, 2000). Metacognitive skills and strategies instruction (e.g., reflection, self-regulation, self-direction) can help students increase their transfer of knowledge and understanding across contexts, settings, and events, providing students with flexibility in learning (Ambrose, Bridges, DiPietro, Lovett, \& Norman, 2010; Bransford, Brown, \& Cocking, 2000; Benander \& Lightner, 2005; Downs \& Wardle, 2007; Zimmerman \& Schunk, 2011). In some settings, knowledge transfer refers to outward and external connections and dissemination of information, but in the context of this study, transfer of knowledge refers to deepening the applicability of material, which may be considered more of an internal or cognitive process.

Metacognition promotes students' "understanding [of] ... cognitive and linguistic process[es]" (Bower, 2003, p. 49) and facilitates professional thinking within and about their discipline (Tanner, 2012). For example, "reflective practice offers the opportunity for thinking about thinking, learning about learning, self-monitoring and regulation" (Mair, 2012, p. 148). To enhance students' metacognition, Tanner, a biology scholar, recommended teaching structured strategies for developing metacognition. Structured strategies, for example, are based on asking questions related to planning, monitoring, and evaluating a project at four points in the course: pre-assessment, the muddiest point in the course, retrospective post-assessment and reflective journaling.

One aspect of metacognition is metacognitive awareness, which "seems to have a reciprocal relationship with self-regulation and students' development of individual writing approaches" (Negretti, 2012, p. 143). As students' metacognitive awareness shifts, they tend to "take more initiative in writing and to self-regulate their writing by developing a personal writing process" (p. 171). Metacognitive awareness has three domains: declarative knowledge (awareness of strategies), procedural knowledge (awareness of how to apply strategies), and conditional knowledge (awareness of when and why to apply strategies; Schraw, 1998; Schraw \& Dennison, 1994; Sperling, Howard, Staley, \& DuBois, 2004). Therefore, metacognitive writing may also lead to awareness of three domains of metacognition in a given context.

If we look at the context of a journalistic writing course, the conditional knowledge domain of metacognitive awareness becomes of special interest. Instrumental to conditional knowledge is students' ability to adapt their writing strategies to meet writing requirements (professional or journalistic style and rules) and to understand why they should adapt their strategies (Negretti, 2012). As such, applying written metacognition in a writing-instruction context may have impacts on learning to write in journalistic or professional contexts. For example, adding purposeful, focused, and specific reflection to the writing process (Parks, 2014; Yancey, 1998) enhances the revision process and the depth of thought during the process. Revision forces students to think about the writing process and the strategies they used to complete the process, providing an avenue of metacognitive awareness (Beach \& Friedrich, 2008).

"Writing is applied metacognition" as thinking is integrated into every part of the writing process (Hacker, Keener, \& Kircher, 2009, p. 160). Implementing metacognitive exercises into writing courses helps students understand and articulate their decision making during the writing process (Cohn \& Stewart, 2016). For example, using metacognitive strategies in a developmental reading and writing course, students "internalize[d] the value" of the writing process and its significance in their college careers (Pacello, 2014, p. 135). Such strategies include generating questions, monitoring 
comprehension, summarizing, rereading when comprehension breaks down, thinking about prior knowledge, establishing a purpose for learning, making predictions, and self-questioning (El-Hindi, 1997; Gourgey, 2003; Laverpool, 2008).

Metacognition can also help students realize their areas of writing incompetence-helping them begin to adjust their strategies to gain competence in their writing ability (Negretti, 2012). Implementing metacognitive instructional strategies into a developmental writing course facilitated students' ability to transfer their understanding of the drafting, revising, and editing processes to other contexts beyond those of the course (Pacello, 2014). The metacognitive reflection in Pacello's study helped one understand writing as a process while becoming more aware of how she writes a message, who she writes to, and how the audience receives the message. Thus, emphasizing "pedagogical methods stressing a metacognitive strategy approach to college reading, writing, and learning might help students to experience the course as being connected to navigating the literacy demands of various academic, professional, and personal contexts" (Pacello, 2014, p. 119).

Reflection links metacognitive awareness with writing practice (Tarricone, 2011). Reflecting on experiences is often as significant to students' growth as the experience itself (Dewey, 1933). As students reflect, they take time to "focus on the cognitive aspects (thinking, problem solving and so on) that led to particular actions, the outcomes and lessons learned from those actions, and how these inform what they might do in the future" (Mair, 2012, p. 148). Students reflect as a way to learn and continuously review tasks and their performance (e.g., Dewey, 1939; Boud, 2001). The reflective process is "a complex one in which both feelings and cognition are closely interrelated and interactive" (Boud, Keough, \& Walker, 1985, p. 11) _it must be intentional and involve the students because reflection has to include the one learning.

Posner, Strike, Hewson, and Gertzog (1982) recognized the importance of retrospective post-assessments, or post-assignment reflection, in helping students' process course material. For example, students completing a reflection after each assignment and at the end of a course is a retrospective post assessment of students metacognitive writing awareness because students are charged with thinking about their writing before and after the assignment. As a result, they are forced to see the changes in their writing ability. Thus, integrating reflection into a writing course is one way to investigate metacognition and metacognitive awareness. Reflection provides the writer an opportunity to become a critic of his or her writing experiences. To be a reflective writer, however, one must be a reflective thinker, which is indicative of how one thinks and constructs meaning about experiences (Mair, 2012). Linkages exist between reflection and writing, reflection and metacognitive awareness, and metacognition and learning, but no few, if any, studies combine each element in a specific, applied journalistic context. So, what happens when students reflect on their metacognitive awareness during and throughout the writing process in a journalistic writing course?

\section{PURPOSE AND RESEARCH QUESTIONS}

This study interpreted students' metacognitive writing through periodic writing reflections in an advanced agricultural media writing course.

1. What did students think about when they reflected on writing?

2. How did students' metacognitive awareness of writing change?

\section{CONTEXT OF STUDY}

This study was situated within the context of an agricultural communications course at Texas A\&M University. The advanced agricultural media writing course was the third course in a three-course sequence and focused on feature writing concepts. Course objectives include preparing learners to tell objective stories, conducting interviews, asking effective questions, writing feature stories, writing clear and concise copy, applying Associated Press style, and using correct writing mechanics. During the fall 2015 semester, the 15-week course was taught by one faculty member and one graduate teaching assistant and met four days a week for two lectures and two writing labs. In weekly lectures, students learned about elements of compelling feature writing, mechanics of AP style, deep writing, and general writing 
practices. In lab sessions, students completed a writing activity that followed and reinforced concepts from the previous lecture. For major course assignments, students completed a column or review, an informational/educational or how-to, and a personality profile or descriptive story. Students received feedback from the instructor in a lab setting, as well as electronically as they submitted assignments, and were given the option to revise assignments for partial credit. After the revision deadline for each assignment and at the end of the course, students completed a reflection exercise.

\section{METHODS}

The methods used in this study were part of the reporting for a larger research project. Methods described here are specific to this study but also served to collect data for a larger project. As such, similar methods may exist as part of another study.

This case study explored students' awareness of metacognitive writing through periodic writing reflections. Case study research "focuses on describing, understanding, predicting, and/or controlling the individual (i.e., process, animal, person, household, organization, group, industry, culture, or nationality;" Woodside, 2010, p. 1). Deep understanding emanating from case studies includes knowledge of individuals' sensemaking with a focus on perceptions, frame of perception, or interpreting results of stimuli or intervention. Therefore, number of participants is not as important as the depth of the understanding in case study research (Woodside, 2010).

This case study was conducted using a qualitative and quantitative content analysis, which was consistent with Woodside's (2010) assertion that case studies use multiple observations over a period of time. Qualitative research determines "how people interpret their experiences, how they construct their worlds, and what meaning they attribute to their experiences" (Merriam, 2009, p. 5). A qualitative content analysis allows one to unobtrusively study written documents as a way of "listening to the words of the text and understanding better the perspective(s) of the producer of these words" (Berg, 2001, p. 242). Thus, through "qualitative data reduction[,] ... sense-making effort[s]," (Patton, 2002, p. 453) and theme recognition, researchers can make sense of participants' experiences and understand how they develop meaning.

Additionally, using Berelson's (1966) methods for quantitative content analyses in communications, researchers can measure message frequency, type, and variety. For example, "units of space most commonly are seen as countable, and therefore, measurable" (Altheide, 1987, p. 66-67). This quantitative treatment of data was consistent with Berelson's (1952) description of quantitative content analysis as "a research technique for the objective, systematic, and quantitative description of the manifest content of communication" (p. 55). Because this study examined how students in a specific course under a purposeful intervention made meaning through reflection exercises and included triangulated data collection with extensive hours of observation and analysis, this project met Woodside's (2010) criteria for deep understanding.

\section{Population}

The population of this study was comprised of Texas A\&M University students enrolled in the course during the fall 2015 semester. Nineteen students enrolled in Agricultural Media Writing II, and of the 19, 16 consented to participate in the study. However, not all 16 students participated in each of the four reflections (RA1 = 14; RA2 = 16; RA3 = 16; RA4 = 16).

\section{Procedures}

Prior to collecting data, we developed a reflection exercise based on our experiences teaching and researching agricultural writing development and on feedback from the writing faculty in the department. The exercise included 12 reflective questions related to students' challenges and success with writing assignments and questions about students' feelings, standards, and lessons learned. Students completed four reflection exercises throughout the semester-the first three at after revising each major assignment and the fourth at the end of the semester. Students' responses on the reflection exercise constituted the data for this study. 
After data collection, we removed students' identifying information from each response and assigned numbers to each student and letters to each reflection period. We broke each student's reflection responses into two-sentence units for analysis and numbered each unit consecutively. To each unit, we assigned codes reflecting the student number, reflection letter, and individual unit number. We excluded some units because of impartial responses, unusable responses, or blank responses. We identified five unusable responses because there was no clear idea or identifiable thought in the reflection response (e.g., sentence fragments, unclear thought structure, or ambiguity). In total, we identified and coded 430 unique units.

To analyze the data, we (two agricultural communications and journalism faculty members and one graduate student) coded each unit using a modified constant comparative method adapted for naturalistic inquiry as described by Lincoln and Guba (1985). Then, we refined, combined, deleted, and/or modified categories as needed to capture the essence of the reflection's content. Following Lincoln and Guba's (1985) theme identification guidelines, we identified course outcomes and performance; confidence; journalistic style; writing skill; revision; audience analysis; researching; interviewing; emotions; future plans; time management; and topic selection in the first round of data analysis. In the second round, we refined the themes. We split course outcomes and performance into outcome (grade) and future plans (absorbing the other future plans theme); combined writing skill and journalistic style into general writing practices; revision, audience analysis, and combined some units from research and interviewing to form a writing process theme; and absorbed emotions into confidence. Once we refined and established these themes, we reviewed each unit in the theme to ensure it met the theme inclusion description. Further refinement led to the creation of three super themes: skills, strategy, and transferability. Final theme orientation and frequency of appearance in each reflection period is shown in Table 1.

After we qualitatively analyzed the data, we aligned the data within each sub-theme and theme for the quantitative content analysis portion of the study. Then, we counted reflection statements for each reflection to show growth and change over the course of the semester.

Given the qualitative paradigm of this study, we established trustworthiness by using Lincoln and Guba's (1985) guidelines for credibility, transferability, dependability, and confirmability. We maintained credibility through triangulation and frequent peer debrief, transferability through thick descriptions and wide inclusion of data. confirmability through field notes and an investigator audit trail, and dependability through triangulation. Additionally, Merriam (2009) noted four types of triangulation in qualitative inquiry: using multiple methods of collection (e.g., observations, interviews, and a review of literature), using multiple sources of data (e.g., data collected at different times), multiple investigators, and multiple theories to confirm data. This study achieved triangulation by using three of the four types of triangulation: multiple investigators, multiple methods of data collection (written reflections, instructor observations, and relevant literature) and multiple sources of data (observations and reflections at multiple times throughout the study).

\section{FINDINGS}

\section{Metacognitive Writing Reflections}

In reviewing students' metacognitive writing reflections, we found students think about writing skills, writing strategies, and transferability of writing strategies and skills. Each of the overarching themes included sub-themes describing its content: skills (general writing practices, interviewing, and researching), strategies (audience, revision, time management, topic selection, and writing process), and transferability (challenges, confidence, emotions, futures, and outcomes). Table 1 shows the frequency and organization of each theme and sub-theme. 
Journal of A pplied Communications, Vol. 101, Iss. 1 [2017], Art. 6

Table 1

Emergent Themes and Sub-themes by Reflection

\begin{tabular}{|c|c|c|c|c|c|c|}
\hline Theme & Sub-theme & $\mathrm{R} 1$ & $\mathrm{R} 2$ & R3 & R4 & Total \\
\hline \multirow[t]{4}{*}{ Skills } & General Writing Practices & 43 & 33 & 20 & 46 & 142 \\
\hline & Interviewing & 7 & 18 & 37 & 2 & 64 \\
\hline & Researching & 8 & 17 & 3 & 1 & 29 \\
\hline & Total & 58 & 68 & 60 & 49 & 235 \\
\hline \multirow[t]{6}{*}{ Strategy } & Revision & 24 & 11 & 1 & 18 & 54 \\
\hline & Topic Selection & 8 & 15 & 10 & 2 & 35 \\
\hline & Writing Process & 8 & 10 & 6 & 5 & 29 \\
\hline & Time Management & 5 & 6 & 2 & 7 & 20 \\
\hline & Audience & 5 & 7 & 0 & 1 & 13 \\
\hline & Total & 50 & 49 & 19 & 33 & 151 \\
\hline \multirow[t]{6}{*}{ Transferability } & Confidence & 15 & 15 & 9 & 15 & 54 \\
\hline & Outcomes & 15 & 15 & 14 & 3 & 47 \\
\hline & Challenges & 8 & 9 & 3 & 5 & 25 \\
\hline & Emotions & 5 & 7 & 1 & 9 & 22 \\
\hline & Future & 1 & 0 & 0 & 9 & 10 \\
\hline & Total & 44 & 46 & 27 & 41 & 158 \\
\hline Total & & 152 & 163 & 106 & 123 & 544 \\
\hline
\end{tabular}

Note: $\mathrm{R} 1$ = reflection one; $\mathrm{R} 2$ = reflection two; $\mathrm{R} 3$ = reflection three; $\mathrm{R} 4$ = reflection four

Metacognitive awareness of writing skills. The first theme emerging from the students' reflection was metacognitive awareness of writing skills $(f=235)$, which included general writing practices $(f=142)$, interviewing skills $(f=64)$, and researching skills $(f=29)$.

First, general writing practices, the most consistent across reflections and most prominent sub-theme of writing skills, consisted of statements about developing specific practices and habits that characterize effective writing. Some of these practices were specific to journalistic writing and Associated Press style and others focused on effective writing in general, regardless of style. Because this study investigated a writing-intensive course in a media writing context, we collapsed both the journalistic style statements and general writing skills statements into one sub-theme to encompass sound writing practices. Those practices do not, however, include interviewing and researching, as those skills were prominent enough to warrant separate sub-themes. Therefore, general writing practices included transitions, voice and style, brainstorming and organization, effective leads and endings, descriptive phrases, grammar and punctuation, clarity, attribution, and humanizing feature stories. This sub-theme captured the true nature of learning to write and some of the most raw and outcome-oriented statements in the study.

In many cases, students' reflections were both practical and ideological. For example, "I learned that I tend to 'over fluff' my paper. I also tend to use too many conjunctions when writing papers" (P21). This participant reflected about an intangible and vague idea (fluff), as well as a pragmatic, measurable practice (overuse of conjunctions). That juxtaposition between intangible writing skills and technical writing practices embodies the essence of this sub-theme. Participant 15 described how writing enables writers and readers to wrestle with ideas of importance: "Draw[ing] conclusions using opinions based on facts and sway[ing] readers gave me a satisfactory feeling, but being able to bring an issue to light that people might not know about was even better." However, participant 26 took a more pragmatic approach to attribu- 
tion and the mechanics of writing - "I revised the way I introduced my second source. I think this made my paper more effective by crediting my source before I quoted him." In each case, participants reflected on their awareness of developing sound writing practices.

Second, interviewing was the next most prominent sub-theme within writing skills. Students reflected about their frustrations in setting up interviews, finding sources, anticipating interview responses, and integrating interview responses into their final projects. One student (P23) reflected "The answers I received from the source were not what I was expecting, which through the whole direction of my paper off." Other students echoed and expounded participant 23 by describing the challenges of planning and executing the interview. For example, "The interview process required the most attention, formulating introspective questions that led to a deep, thought provoking answer from the interviewee" (P15).

Third, researching was the final sub-theme of writing skills. Reflections about research were characterized by types of sources, credibility of sources, and balancing interests with sound research practices. While reflecting, students focused on their lack of research and recognized they should have done more research. One of the commonalities among the reflections was students' need to improve their interview practices. Participant 18 captured this most effectively, "I have learned that you have to do thorough research if you want to write a reliable article, and I take ownership over my lack of research." Although "...research was the most difficult part, it was also the most satisfying" for participant 27.

Metacognitive awareness of writing strategies. Five emergent sub-themes contributed to students' metacognitive awareness of writing strategies $(f=151)$ : Revision $(f=54)$, topic selection $(f=35)$, writing process $(f=29)$, time management $(f=20)$, and audience $(f=13)$.

First, students reflected on revision, a writing strategy, most frequently. Students' statements about revising strategies included making multiple revisions and edits, using peer review, soliciting feedback, and emphasizing the positive outcomes of multiple revisions. For example, participant 20 described revising an assignment six times before submission. Similarly, participant 21 noted a new awareness of the importance of revising: "I will take the revision process more seriously. I will take more time editing my paper to make it meet full potential." Soliciting feedback from peers was an important component of revision. "I think the biggest strategy I have learned is to let other people view my paper. Several sets of eyes on your paper helps catch mistakes" (P13). Participant 11 echoed the value of peer review in revision: "My peers helped me notice errors that I had not caught in my 50 plus times of reading my article." Additionally, instructor feedback played a pivotal role in the revision process. Participants 12 and 16 described major reworks of assignments based on instructor feedback. For example, "I took extra time to sit down with my professor and talk through his critiques" (P18).

Second, students demonstrated an awareness of writing strategy related to topic selection. This sub-theme differed from the audience awareness sub-theme because topic selection explored identifying topics student authors found interesting and audience awareness explored identifying material relevant to the audience. Students frequently referenced their passion for or against a topic. Students who expressed difficulty identifying a topic that interested them also discussed their disappointment or dissatisfaction with their end product while students who identified topics important to them typically expressed their satisfaction and contentment with their work. Participant 22 called it writing about "things that matter," and participant 14 enjoyed writing about topics that interested her and targeting a publication she would read. Conversely, participant 26 wrote "I honestly didn't like my paper at all. I wasn't passionate about what I was writing about so that made it difficult to even complete my assignment."

Third, students also described thinking about writing as a process rather than a one-time activity. Reflection statements about ways students discovered and implemented a process characterized the writing process sub-theme. Many students identified steps or benchmarks for completing the process while others expressed the importance of writing in multiple settings because it was a more complex process than they initially perceived. For example, "I learned I work better if I give myself tiny breaks throughout my time writing" (P07). Participant 10 also reflected about an awareness of new strategies enhancing the writing process: "I tend to do 'word vomit' when I write. Instead, if I consciously think about each word I always have a more successful outcome." 
Fourth, time management also emerged as part of the writing strategy theme. When reflecting on managing time, students noted budgeting time through each step, managing deadlines, planning ahead, avoiding procrastination, and allowing for unexpected setbacks as important to the writing process. Even early in the course, some students articulated a purposeful approach to time management. As an example, "my goal for major assignment one was to not procrastinate and get a good grade on the assignment. I made sure to start my paper two weeks before and work on it constantly throughout" (P24). Yet, time management challenged students as reflections on their difficulty managing time or on their shortcomings regarding effective time management were more frequent than reflections indicating effect time management.

Fifth, students' reflected about audience awareness. These reflections were typified by students' recognition that audiences are important and that researching and analyzing audiences requires a strategy. Participant 12 described the development of that awareness: "I think I've developed a writing behavior where I study my reader first, then cater my paper to the specific interests of the reader." Yet, other participants described crafting audience specific stories as challenging and difficult because, for them, the audience analysis and audience-centered writing strategy was the most challenging part of feature writing.

Metacognitive awareness of knowledge transfer. The final theme emerging from students' metacognitive reflections was an awareness of knowledge transfer and factors inhibiting knowledge transfer. For some students, the idea of successful knowledge transfer manifested through changes in confidence regarding writing skill $(f=54)$, changes in the nature of desired course outcomes $(f=47)$, or future plans and career ambitions $(f=10)$. For others, reflection about knowledge transfer took the form of identifying challenges $(f=25)$ or working through emotions as a part of writing $(f=22)$.

The most prominent sub-theme of knowledge transfer was an awareness of confidence. Most reflection statements in this sub-theme communicated students' enhanced confidence in their writing ability. Participant 18 described her awareness of enhanced confidence as "I am confident enough in my paper that I wouldn't mind sending it to [a] publication to see if it would actually run. I'm usually very self-conscious about my writing." Participant 22 echoed having enough confidence in her writing to submit her work for publication. Thus, overall, students described awareness of knowledge transfer as having a skill they previously doubted, growing from failure, and discovering their abilities and limitations.

Students' awareness of knowledge transfer was also evident in their reflections about desired course outcomes. This subtheme was dichotomous in nature-some students desired real-world impact from the course and its assignments while others simply desired a good grade on their work. For example, participant 11 described developing effective writing skills to confidently share her work with the subject of her story; whereas, participants 21 and 23 reflected about their final grade rather than the outcome and impact of their writing. Participant 20 adopted an especially realist philosophy concerning desired course outcomes: "The main goal of the entire assignment was to make a good grade. How I go about reaching this goal for major assignment 2 will change since my strategy didn't work for major assignment 1." Alternatively, participant 27 offered a more idealist philosophy: "My goal was to educate the reader and maybe even change their minds about the topic. I hope I was able to do that!"

Similar to the outcomes sub-theme, some students reflected on future plans as a result of knowledge gained in this course. These reflections identified specific jobs students saw as possibilities for future employment-public relations writing, freelance writing, and magazine production. Other reflections included the importance of writing for careers in general. For example, "every job, especially communications-based jobs, require writing skills so I know I will take a lot away from this class" (P18).

Many students, however, chose to reflect on challenges to the learning process in a writing course. These challenges ranged from contextual ("I did not grow up on a farm or have a horse in my house like others in this class, so it's hard for me sometimes to understand agriculture the way my classmates do;" P12) to philosophical ("I learned that thoughts come easy to me; however, putting those thoughts on paper is difficult;" P13) to mechanical (uncertainty about perspec- 
tive across multiple assignments and its limit on success; P24). Ultimately, this sub-theme was characterized by students wrestling with concepts like "leaving my comfort zone" and using writing to solve problems.

Finally, some students recognized the emotional connection to knowledge transfer and writing. Some students discussed emotions with positive connotations, like gaining a new love for writing, while others discussed emotions with negative connotations, like discovering a dislike for writing. In both cases, students described how emotions coalesced learning and translated into knowledge gains. As an example, participant 11 noted, "I learned I fear writing and I fear negatives. Getting started on an assignment is my biggest struggle."

\section{Change in Metacognitive Awareness}

RQ2 focused on the students' change in metacognitive awareness and the distribution of themes and sub-themes across the four reflection periods (Table 1). In the first (R1), second (R2), and fourth (R4) reflection periods, participants thought about general writing practices. Yet, in the third reflection period (R3), students thought about interviewing skills.

One way to look at change across reflections is to compare the most frequently appearing sub-themes or topics in each reflection. In the first reflection period (R1), participants thought about general writing practices $(28.29 \% ; f=43)$ and about revision (15.79\%; $f=24$ ) of the time. During the second reflection period (R2), participants reflected about general writing practices $(21.71 \% ; f=33$ ) and about interviewing $(11.84 \% ; f=18)$. The third reflection (R3) was the only period participants reflected most frequently on a sub-theme other than general writing practices. In fact, in R3 students reflected on interviewing (24.34\%; $f=37$ ) and on writing practices $(13.16 \% ; f=20)$. In the final reflection, students thought about general writing practices $(30.26 \% ; f=46)$ and revision $(11.84 \% ; f=18)$.

There were notable changes in the frequency that students reflected on certain sub-themes across the reflection periods. For example, more than half $(57.81 \% ; f=37)$ of the reflections about interviewing skills appeared in R3, which was immediately after the personality profile assignment. Similarly, 58.62\% $(f=17)$ of the reflections about research appeared in R2, which was immediately after the informational or educational article assignment. Students reflected about revision more at the beginning of the course $(\mathrm{R} 1 ; 44.44 \% ; f=24)$ and at the end of the course (R4; $33.33 \% ; f=18)$ than they did in R2 and R3 combined ( $f=12)$. Students thought more about topic selection after the second assignment $(42.85 \% ; f=$ 15) than they did during any other period and thought more about the future almost exclusively at the end of the course (R4; 90.00\%; $f=9$ ). 


\section{CONCLUSIONS, RECOMMENDATIONS, \& IMPLICATIONS Metacognitive Writing Reflections}

Reflections are often integrated into curriculum to provide students an opportunity to document their learning and think about their experiences. Throughout the semester, students in this study reflected on their writing skills, writing strategies, and transferability of writing strategies and skills. Coinciding with Posner et al. (1982), students used the retrospective post-assessments (reflections) to enhance their understanding of writing skills and strategies and think about how they plan to transfer their new understandings. Students' metacognitive awareness during the reflections helped them identify their areas of writing incompetence and adjust their strategies as necessary to achieve their goals on the next assignment, which complemented Negretti's (2012) findings.

Students consistently reflected on their general writing practices throughout the semester; therefore, developing specific practices and habits that characterize effective writing were at the forefront of their mind. In addition, they thought about interviewing, revision, confidence, and outcomes more than they thought about any of the other sub-themes. Looking at the data, one can see students focused on writing skill development and were not as aware of developing writing strategy or transferring writing skills and strategies. Although students were not as aware of transferring writing skills and strategies as they were of writing skills, the reflections show they began thinking about how skills and strategies transfer. This complements Ambrose et al. (2010), Bransford et al. (2000), Benander and Lightner (2005), Downs and Wardle (2007), and Zimmerman and Schunk (2011) who noted metacognitive skills and strategies instruction facilitates knowledge transfer.

As we investigated students' movement through the three domains of metacognitive awareness (Schraw, 1998; Schraw \& Dennison, 1994; Sperling, Howard, Staley, \& DuBois, 2004), students became aware of important writing skills and strategies and started to become aware of how to apply those skills and strategies. However, they did not reach an awareness of when and why to apply writing skills and strategies. Thus, we concluded students gained declarative and procedural knowledge in the course, but we do not have evidence for or against them gaining conditional knowledge. This evidence emerged as declarative knowledge when students identified skills and strategies that helped them develop as writers and as procedural knowledge when they developed a process for completing writing skills and strategies.

Because metacognitive skills and strategies instruction (e.g., reflection) enhance students' ability to become of aware of writing skills gained and writing strategies deployed, reflection should be integrated into writing courses as retrospective post-assessments. Reflection, in this study, was instrumental in facilitating the change process as students developed writing skills and strategies and identified ways to transfer their knowledge and understanding. We know students have the ability to gain declarative and procedural knowledge because it was evident in this study and others. However, conditional knowledge did not manifest in this data. Therefore, instructors should be more intentional about targeting conditional domains of metacognition through purposeful strategies in an effort to capture all three domains of metacognitive awareness.

Future research should focus on when students should engage in the reflection process throughout the semester. If reflection does enhance students' ability to transfer writing skills and strategies as it did in this course and it has in others, researchers should seek to understand how often and at what points reflection should be integrated into the curriculum. Additionally, more research should be conducted on how (e.g., assignments, reflections, exercises) students reach a conditional knowledge domain in a 15-week writing course. Perhaps, students cannot obtain conditional knowledge in one semester, which should be documented as well.

\section{Change in Metacognitive Awareness}

Interviewing skills were most important to students in the third reflection. This may be attributed to the personality profile assignment, as it required more interviews than other assignments. It might also be that students think more about interviewing as they progress as writers. Students reflected more about revising at the beginning and end of the course than they did in the middle of the course. Therefore, reflecting on revising may be most relevant to new and develop- 
ing writers, which would support Lingwall and Kuehn's (2013) assertion that reflection is key in developing surface-level writers into deep writers. The idea of revising reappeared when students reflected on the course as a whole. In contrast, students thought more about topic selection earlier in the course, which may indicate that as they progressed as writers they became better at choosing topics or that the topic mattered less as they became more experienced writers. Unsurprisingly, students did not reflect as much about their future as writers or about their career ambitions until the end of the course.

In this study, the reflective process complemented the revision process, especially near the beginning and end of the class. This complements the findings of Parks (2014) who advocated for purposeful and focused reflection to enhance revision. Cohn and Stewart (2016) found metacognitive exercises helped students understand their decision-making. Participants in this study thought more about writing strategies they should apply at the beginning of the course than at the end. This could be indicative of enhanced decision-making, enabled through metacognition, which would support Cohn and Stewart's findings and Negretti's (2012) assertion that strategy development is enhanced and competencies are gained through metacognition. Additionally, Pacello (2014) found metacognitive instructional strategies encouraged concept transferability beyond the course. Thus, students in this study began to apply concepts to their futures as writers and think about their careers in this study, complementing Pacello's work.

Because students' metacognitive awareness changed throughout a writing course, instructors in agricultural communications and similar fields should be aware of the need for adapting metacognitive instructional strategies. Adapting such strategies will enhance and encourage changing metacognitive patterns, which may further develop writing competence (Negretti, 2012). Instructors should also be aware that the nature of assignments may influence the nature of students' reflection. This is important in planning the order and impact of assignments. In this study, students thought more about interviewing skills while working on a personality profile and more on research skills while working on an educational article. As such, instructors who view research as foundational to interviews (or vice-versa) should consider the impact of metacognitive awareness to ensure students are working through ideas in the right order and building effective foundations.

Future research on metacognitive writing should include quantitative measures to document changes in competencies as this study did not explore if changes in metacognitive awareness were related to changes in competency. Additional future research should compare the patterns of metacognitive awareness in this population to the patterns of others. Do students in a beginning news writing course show similar changes in metacognitive awareness? Does change in reflection occur in similar order and magnitude for students in non-agricultural contexts?

Agricultural communications and journalism professionals and other career professionals who write as part of their daily job should consider metacognitive exercises to document their writing development and enhance their understanding of writing concepts. Knowing what students thought about when they reflected on writing will enable the industry to continue to prepare and develop effective writers to tell the story of agriculture.

\section{REFERENCES}

Altheide, D. L. (1987). Reflections: Ethnographic content analysis. Qualitative Sociology, 10(1), 65-77.

Ambrose, S. A., Bridges, M. W., DiPietro, M., Lovett, M. C., \& Norman, M. K. (2010). How learning works: Seven re search-based principles for smart teaching. San Francisco, CA: Jossey-Bass.

Beach, R., \& Friedrich, T. (2008). Response to writing. In C. A. MacArthur, S. Graham, \& J. Fitzgerald (Eds.), Handbook of writing research (pp. 222-234). New York, NY: Guilford.

Benander, R., \& Lightner, R. (2005). Promoting transfer of learning: Connecting general education courses. The Journal of General Education, 54(3), 199-208. doi: 10.1353/jge.2006.0001

Berelson, B. (1952). Content analysis in communications research. Glencoe, IL: The Free Press. 
Berelson, B. (1966). Content analysis in communication research. In B. Berelson, \& M. Janowitz (Eds.), Reader in Public Opinion and Communication (pp. 260-266). New York, NY: The Free Press.

Berg, B. L. (2001). Qualitative research methods for the social sciences. Needham Heights, MA: Allyn \& Bacon.

Bower, L. L. (2003). Student reflection and critical thinking: A rhetorical analysis of 88 portfolio cover letters. Journal of Basic Writing, 22(2), 47-66. Retrieved from http://www.jstor.org/stable/43443774

Bransford, J. D., Brown, A. L., \& Cocking, R. R. (2000). How people learn: Brain, mind experience, and school. Washington, DC: National Academy Press.

Boud, D., Keogh, R., \& Walker, D. (1985). What is reflection in learning? In D. Boud, R. Keogh, \& D. Walker (Eds.), Reflection: Turning experience into learning (pp. 7-17). New York, NY: Nichols Publishing.

Boud, D. (2001). Using journal writing to enhance reflective practice. New Directions for Adult and Continuing Education, 2001(90), 9-18. doi: 10.1002/ace.16

Carpenter, S., Grant, A. E., \& Hoag, A. (2016). Journalism degree motivations: The development of a scale. Journalism and Mass Communications Educator, 71(1), 5-27. doi: 10.1177/1077695814551835

Cohn, J. D., \& Stewart, M. (2016). Promoting metacognitive thought through response to low-stakes reflective writing. Journal of Response to Writing, 2(1), 58-74. Retrieved from http://www.journalrw.org/index.php/jrw/article/ view/51

Dewey, J. (1933). How we think: A restatement of the relation of reflective thinking to the educative process. Boston, MA: Heath.

Dewey, J. (1939). Experience, knowledge and value: A rejoinder. In P. Schilpp (Ed.), The philosophy of John Dewey (pp. 517-608). Evanston, IL: Northwestern University.

Downs, D., \& Wardle, E. (2007). Teaching about writing, righting misconceptions: (Re)envisioning "First-year composition" as "Introduction to writing studies." College Composition and Communication, 58(4), 552-584. Retrieved from http://www.jstor.org/stable/20456966

El-Hindi, A. E. (1997). Connecting reading and writing: College learners' metacognitive awareness. Journal of Developmental Education, 21(2), 426-451.

Flavell, J. H. (1976). Metacognitive aspects of problem solving. In L. B. Resnick (Ed.), The Nature of Intelligence (pp. 231235). Hillsdale, NJ: Lawrence Erlbaum Associates.

Gourgey, A. F. (2003). Teaching reading from a metacognitive perspective: Theory and classroom experience. In N. A. Stahl \& H. Boylan (Eds.), Teaching developmental reading: Historical, theoretical, and practical background readings (pp.126-134). Boston, MA: Bedford/St. Martin's.

Hacker, D. J., Keener, M. C., \& Kircher, J. C. (2009). Writing is applied metacognition. In D. J. Hacker, J. Dunlosky, \& A. C. Graesser (Eds.), Handbook of metacognition in education (pp. 154-172). New York: Routledge

Kavcar, C., Oguzkan, F., \& Sever, S. (2012). Turkce ogretimi - Turkce ve sinif ogretmenleri icin [Turkish education - for Turkish and classroom teachers]. Ankara: Engin Yayinevi.

Kuzu, S. T. (2016). The impact of a semiotic analysis theory-based writing activity on students' writing skills. Eurasian Journal of Educational Research, 63, 37-54. doi: 10.14689/ejer.2016.63.3

Laverpool, A. (2008). The efficacy of rereading as a metacognitive tool for reading comprehension monitoring. Journal of College Reading and Learning, 38(2), 31-48. doi: 10.1080/10790195.2008.10850307

Leggette, H. R., Rutherford, T. A., \& Dunsford, D. W. (2015). A Model to Augment Critical Thinking and Create Knowl edge through Writing in the Agricultural Social Sciences.-NACTA Journal, 59(3), 245-251. Retrieved from https://nactateachers.org/index.php/volume-59-number-3-september-2015

Lincoln, Y., \& Guba, E. (1985). Naturalistic Inquiry. Beverly Hills, CA: Sage.

Lingwall, A., \& Kuehn, S. (2013). Measuring student self-perceptions of writing skills in programs of Journalism and Mass Communication. Journalism \& Mass Communication Educator, 68, 365-386. doi: 10.1177/1077695813506991

Mair, C. (2012). Using technology for enhancing reflective writing, metacognition and learning. Journal of Further and Higher Education, 36(2), 147-167. doi: 10.1080/0309877X.2011.590583

Merriam, S. B. (2009). Qualitative research: A guide to design and implementation. San Francisco, CA: Jossey-Bass.

National Research Council, (2000).How people learn: Brain, mind, experience, and school, Washington, DC: National Academies Press. 
Negretti, R. (2012). Metacognition in student academic writing: A longitudinal study of metacognitive awareness and its relation to task perception, self-regulation, and evaluation of performance. Written Communication, 29(2), 142179. doi: $10.1177 / 0741088312438529$

Nist, S. L., \& Simpson, M. L. (2000). College studying. In M. L. Kamil, P. B. Mosenthal, P. D. Pearson, \& R. Barr (Eds.), Handbook of reading research (pp. 645-666). Mahwah, NJ: Erlbaum

Pacello, J. (2014). Integrating metacognition into a developmental reading and writing course to promote skill transfer: An examination of student perceptions and experiences. Journal of College Reading and Learning, 44(2), 119140. doi: $10.1080 / 10790195.2014 .906240$

Parks, A. R. (2014, November). What were you thinking?: Using rhetorical stories to teach metacognition in the writing classroom. Presentation at the NCTE annual convention, Washington, DC.

Patton, M. Q. (2002). Qualitative research and evaluation methods (3rd ed.). Thousand Oaks, CA: SAGE Publications.

Poniatowski, K. (2012). Getting students ready to write: An experiment in online teaching and learning. Journalism and Mass Communications Educator, 67(2), 120-133. doi: 10.1177/1077695812440943

Posner, G. J., Strike, K. A., Hewson, P. W., \& Gertzog, W. A. (1982). Accommodation of a scientific conception: Towards a theory of conceptual change. Science Education, 66(2), 211-227. doi: 10.1002/sce.3730660207

Schraw, G. (1998). Promoting general metacognitive awareness. Instructional Science, 26(1), 113-125. doi: 10.1023/A:1003044231033

Schraw, G., \& Dennison, R. S. (1994). Assessing metacognitive awareness. Contemporary Educational Psychology, 19(4), 460-475. doi: 10.1006/ceps.1994.103-

Sperling, R. A., Howard, B. C., Staley, R., \& DuBois, N. (2004). Metacognition and self-regulated learning constructs. Educational Research and Evaluation, 10(2), 117-139. doi: 10.1076/edre.10.2.117.27905

Tanner, K. D. (2012). Promoting student metacognition. CBE-Life Sciences Education, 11(2), 113-120. doi: 10.1187/ cbe.12-03-0033

Tarricone, P. (2011). The taxonomy of metacognition. New York: Psychology Press.

Woodside, A. G. (2010). Case study research: Theory, methods and practice. Bingley, UK: Emerald Group Publishing.

Yancey, K. B. (1998). Reflection in the writing classroom. Logan, UT: Utah State University Press.

Zimmerman, B. J., \& Schunk, D. H. (2011). Handbook of self-regulation of learning and performance. New York: Routledge.

\section{ABOUT THE AUTHORS}

Dr. Tobin D. Redwine is an assistant professor at Texas A\&M University in the Department of Agricultural Leadership, Education, and Communications. Redwine investigates storytelling, including narrative discovery, meaning-making, and messaging practices in agricultural communications and journalism. His line of inquiry examines messaging across multiple media, including visual, written and interpersonal communications.

Dr. Holli. R. Leggette is an assistant professor at Texas A\&M University in the Department of Agricultural Leadership, Education, and Communications. Leggette's research is focused on understanding, evaluating, and improving writing skills of the present and future professionals in agriculture. Much of her work is based on her conceptual model to augment critical thinking and create knowledge through writing in the social sciences of agriculture.

Ms. Brooke Prather is a communication specialist for Texas A\&M AgriLife Extension Service in AgriLife Communications. Her research interests include visual communication and marketing. Prior to completing her master's degree, she was a contributing writer for The American Brahman Review@ and served as Associate Editor for two years. 